\title{
Ukraine's Transition from Soviet to Post-Soviet Law: Property as a Lesson in Failed Regulation
}

\author{
Paul Babie \\ Adelaide Law School, The University of Adelaide
}

\begin{abstract}
This article traces the parallel developments of the Ukrainian transition from Soviet to post-Soviet law and from state to private property. To do this, the article is divided into four parts. The first examines the transition of the Ukrainian legal system from pre-Soviet to post-Soviet law. The second traces the microcosm of that transition as it occurred through the failed adoption of private property introduced in the law of post-Soviet Ukraine. The third demonstrates that the flawed approach by which private property has been adopted, with little if any real and effective regulation in post-independence Ukraine, has produced negative consequences for the Ukrainian people. The final part concludes.
\end{abstract}

Keywords: Ukrainian Law, Soviet Law, Civil Law, Post-Soviet Law, Property, Obligation, Regulation

\section{INTRODUCTION: WhAT A DIFFERENCE A DECADE MAKES}

In 2004 I wrote that Ukraine's "Orange Revolution" of 2004-2005 demonstrated Ukraine's commitment to breaking ties with its Soviet socialist past and to establishing itself fully as a capitalist market economy (Babie, "Morality of Private Property" 271). How wrong could I be; it almost seems as though nothing has changed since immediately before the Orange Revolution. Indeed, in the ten years since, Ukraine has been the very model of how a nation can get it all so wrong in attempting to make the transition from socialism to capitalism (assuming, of course, one wants to make that transition). Corruption, mismanagement, lack of economic growth, an

This article draws on two earlier publications: Babie, "Morality of Private Property"; Babie, "The Spatial", especially at 364-8. I am most grateful to Richard Sletvold (LLB 2013), Holly Ritson (LLB 2014), and Seb Tonkin (LLB 2014) for invaluable advice, assistance, research, intellectual camaraderie, and friendship along the way. Two anonymous reviewers provided perceptive and helpful comments; I am indebted to both. Any remaining errors are entirely my responsibility. 
inability to form a working government, rising wealth inequality-Ukraine excelled at them all (Wilson 311-341).

And it all came to a head almost a decade later in the Euromaidan and ensuing 2014 Revolution, which sparked the crisis with Russia and the eventual annexation of the Crimea and Sevastopol by pro-Russian separatists, supported by Russia as part of its ongoing dispute with Ukraine. The detail of the events of late 2013 and 2014 are beyond the scope of this article. Rather, there is an overarching, but overlooked (and now, understandably so) point that I want to make here, as I made in 2004.

In the flurry of rhetoric in 2004 about a former Soviet state achieving independence and sovereignty (on the history of Ukraine's independence since 1991 and on the 2004-2005 Orange Revolution, see Kuzio and Wilson; Motyl; Wilson; D’Encasse; Solchanyk; Harasymiw; Åslund and McFaul), moving from a socialist past to a capitalist future (on this process, see Amsden, Kochanowicz and Taylor), few seemed directly to address the issue of private property; there seemed to be very little mention, at least in the popular media, of the shape of a right to private property in Ukrainian law. This was surprising in view of the fact that this is a basic prerequisite to a market economy. It continued to be surprising throughout the decade leading to Euromaidan-it is no longer surprising today, of course, given the crises Ukraine currently faces. Yet it is worth considering the issue, for two reasons. First, it tells us something generally about the process of emerging from a socialist economy and legal system and moving to a capitalist and post-Soviet economy and legal structure. Second, and perhaps more importantly, it stands as a warning not only to Ukraine, but also, and more importantly, to other nations, about the perils of moving too quickly in adopting the concept of private property.

Here's why.

Joseph William Singer, four years before the Orange Revolution, in order to explain how private property works, wrote about how one would go about advising the prime minister of the new government of a hypothetical "Eastern European country that has just emerged from communism and is seeking to institute a private property regime" (140-41). He wrote:

[A]s an advocate of private property, you recommend that the government organize a program to privatize government-owned industries, housing, and farms. Your goal is to create a free and democratic society characterized by individual liberty and a market economy. Imagine your reaction if the prime minister proudly announced to you that the government had privatized all its properties in one day by handing out all the land, buildings, and industry in the country to the ten families who had 
formed the crux of the aristocracy in the nineteenth century. Those owners were chosen because their families had historic roles of leadership and could be trusted to guide the country out of the darkness of dictatorship and into the bright future of freedom. These new owners are free to do what they want with their property. Everyone is free to make a living without government interference-no more government ownership, no more communism, no more welfare, no more regulation. All the state will do is enforce property and contract rights and protect individuals from personal harm. With the establishment of private property, the prime minister looks forward to joining the free world, where individual initiative and personal responsibility reign-no more coercion, no more oppression, no more government handouts, no more restrictions on liberty. Of course, some kind of court system and police force will be necessary to protect these new rights and to enforce their attendant obligations, but that is a minor detail. ... You would think the prime minister had a screw loose. (140-41)

Singer could not have been telling the story of post-independence Ukraine more closely if he had tried (and perhaps he was, writing ten years after Ukraine's independence). Yet, this concern with private property is merely a microcosm of the larger issue of the transition from a socialist legal structure to a post-socialist civilian system. That transition was, and is, far from ideal, and the flawed adoption of private property serves to demonstrate the difficulties encountered and the consequences that have been suffered as a result (on the problems associated with a flawed transition, see Raff).

It needs to be said, however, that the cautionary tale of the failure of private property in Ukraine, as told in this article, focusses on what we might call the "formal law" or "positive law"-that law enacted by legislatures structuring the nature, role and operation of private property. Yet this focus ought not be taken as a denial of the importance of "informal law"-the "rules of the game" that operate at the social level, amongst people, often within the structure of the formal law, but often times outside of it-in understanding Ukraine's private property. Such informal rules are increasingly coming to be seen as part of the totality of the law to which any person is constantly subject, often without even knowing it. In fact, rather than one legal system, "law" is a complex, sometimes bewilderingly so, interplay of many "systems" of law that go far beyond what we typically think of law. William Twining neatly summarizes the contemporary global legal landscape or, in other words, what law, in its complexity, in its totality, actually is:

(i) . . . supranational, sub-national and trans-national levels of legal relations: public international law, European Commmunity (sic) law, 
Islamic law, Maori law, and lex mercatoria for example. (ii) . . the [law of the] major legal traditions in which law is not conceptually or politically tied to the idea of the state. For example, ... Islamic law [although a narrow definition of law] confines it to countries in which Islamic law is formally recognized as a source of municipal law. But it is obvious that this distorts the extent, scope, and nature of shari'a. (iii) However, if we decide to include major religious and customary normative orderings, and perhaps other examples of non-state law, we run into major conceptual problems. First, we have to adopt a conception of law that includes at least some examples of "non-state law." That re-opens the Pandora's box of the problem of the definition of law and all its attendant controversies. Second, there is the problem of individuating legal orders. What counts as one legal order or system or unit for the purposes of mapping? How does one deal with vaguely constituted agglomerations of norms, which may be more like waves or clouds than billiard balls? (iv) If one decouples the notion of law and state, one is confronted with another set of problems. If one moves away from the idea of one kind of institution having a legitimate claim to monopoly of authority and force, one has to accept the idea of legal and normative pluralism-i.e. the co-existence of more than one legal order in the same time-space context-and all the difficulties that entails. ("Law, Justice and Rights" 79. See also Twining, General Jurisprudence xi-xx and 1265)

It is not possible, then, to rely only upon the formal law of the state in order to produce the desired economic outcomes of a system of private property. Indeed, even if it is perfectly crafted in a timely way, it may be the case that the formal law of a state will not have much, if any, effect, in isolation from accounting for the totality of law as Twining understands it. In short, both formal and informal law together constitute "the law" of a state, and must be accounted for if one seeks to understand the operation of any aspect of law, such as private property.

Moreover, whether a state achieves the outcomes sought in a capitalist economy depends upon both its stage of economic development as well as on the balance of this formal and informal law; getting the balance wrong results in the failure to meet desired economic objectives (Heine). Simply borrowing from another legal culture cannot, of itself, substitute for the long cultural growth that must accompany something as complex as the transition from socialist to capitalist property; there is simply no substitute for this long, and often painful process (Foljanty). Ukraine stands as an ideal-type of both the expectation that simple transplantation of the western concept of private property would be enough on its own, and of the resulting failure; and both the formal system and the informal rules of the game have played their own starring roles in this tragedy (see Markus). Yet this article leaves the role played by informal law in Ukraine's experience with private property to a future project; others have already told that part 
of the story (Markus; Wenar) and it is simply beyond the scope of the present article. But a full account will ultimately be necessary.

The first step in providing that account involves an examination of the formal law and the negative consequences that follow from an insufficiently developed formal regulatory framework for the operation of private property within that formal structure.

To trace these parallel developments-the process of transition from socialist economy and legal system to capitalist, post-Soviet economy and legal structure, and the admonition concerning the perils of moving too quickly in adopting the concept of private property-the article is divided into four parts. Part II examines the transition of the Ukrainian legal system from pre-Soviet to post-Soviet law. Part III traces the microcosm of that transition as it occurred through the failed adoption of private property introduced in the law of post-Soviet Ukraine. Part IV demonstrates that the flawed approach by which private property has been adopted with little if any real and effective regulation in post-independence Ukraine has produced negative consequences for the Ukrainian people. Part V concludes.

\section{UKRAINIAN CIVIL LAW AND THE COURTS}

\section{BACKGROUND}

On 26 August 1991, the Verkhovna Rada, the Supreme Council of Ukraine, declared Ukraine to be an independent state (see Wilson 152-171; Wolczuk; Subtelny). Although a defining moment in its history, Ukraine's independence had none of the hallmarks of the proud revolutionary moment experienced by other former Soviet states. Indeed, independence came slowly to Ukraine, more a gradual process of disgruntled communist elites moving away from the distracted central government in Moscow than a dramatic autochthonous break. Ukraine's long history of occupation either by Russia or the Soviet Union meant that many living within its borders were either Russian or Russophone, which militated against a dramatic nationalist movement, such as was witnessed in the Baltic States (Wilson 161).

Still, independence did come, ascribed largely to (a) the Ukrainian communist elite's dissatisfaction with perestroika, Mikhail Gorbachev's policy of openness; and, (b) the Soviet central government's failure effectively to respond to the Chernobyl disaster of 1986, which in turn cast further doubt on whether the USSR actually had an interest in Ukraine. The 1990 elections to the Ukrainian Supreme Soviet revealed this growing Ukrainian disillusionment with the USSR; Leon Kravchuk was elected chairman of the Ukrainian Soviet Socialist Republic (UkSSR) Supreme 
Soviet (Wilson 163). Finally, in August 1991, the failed coup d'état in Moscow proved to be enough to trigger a declaration of independence.

Following the declaration of independence, the Parliament of Ukraine called a referendum for 1 December 1991 in order to legitimize the newly independent state. While over $92 \%$ of Ukrainians voted in favor of independence, what this independent state would look like was yet to be determined. Indeed, the way in which independence came about-as a gradual process of moving away from Moscow, rather than a step towards an alternative model of governance-meant that the newly established government lacked the vision and direction necessary rapidly to establish effective institutions of governance. This clunky transition led to economic, political and constitutional crises in Ukraine's independent era, as has been seen acutely since mid-2014. Nonetheless, legal reform did come to Ukraine, haphazard though it might have been.

\section{LEGAL SYSTEM}

\section{PRE-SOVIET}

Prior to the implementation of Soviet socialist law in 1920, Ukraine enjoyed an extensive civilian legal history. As early as 1743, the then Ukrainian state had developed a code of laws that underpinned the Ukrainian legal system in the $17^{\text {th }}$ and $18^{\text {th }}$ centuries (Internet Encyclopedia of Ukraine, "Code of Laws of 1743"). Before this, Ukraine was governed by customary law, which was codified around the $11^{\text {th }}$ CCE in the Rus'kaia Pravda (Internet Encyclopedia of Ukraine, "Law"). Subsequent occupying states recognized this Ukrainian customary law, which included substantive and procedural law, but lacked distinctions between public and private law and criminal and civil law that we take for granted in the modern western legal tradition.

The end of the $18^{\text {th }}$ century brought the end of an autonomous Ukrainian state, as Ukraine became part of the pre-revolutionary Russian Empire. The Russian legal system at the time was based on the GermanoRoman civilian tradition introduced through Byzantium (Biryukov 55; Lehman 195). As part of the Russian Empire, Ukraine also adopted the civilian system, which remained in place until the introduction of Soviet law in the early $20^{\text {th }}$ century, including during Ukraine's struggle for and moments of independence between 1917 and 1920 (Internet Encyclopedia of Ukraine, "Law").

\section{SOVIET}

An "outgrowth" of the pre-existing civilian traditions of the Russian Empire, Soviet law built upon "the civil law tradition of system and order" (Lehman 195). Not surprisingly then, as it was a republic in name only, the establishment of the UkSSR as part of the USSR brought about significant 
changes to the Ukrainian legal system; the central Soviet government applied Soviet law to the content of UkSSR legislation (Kossak; Kryvonos 2).

While the structure of the UkSSR's former legal system remained, the substantive law changed remarkably. The Soviet legal system imposed socialist ideological principles throughout the civil system. Notably, adhering to V. I. Lenin's statement that "everything was public law by nature" (Bulkina 601), this imposition resulted in the abolition of the concept of private law. This had radical consequences: in the case of private property, for instance, the concept was completely removed and replaced with communally and state-owned property, thereby facilitating a centrally planned economy.

The Soviet Constitutions of Ukraine contained the public law of the UkSSR, and this generally governed the legal system of the state. The last such constitution came into force in 1978, each having been based on the USSR constitution at the time (Internet Encyclopedia of Ukraine, "Constitution of the Ukrainian Soviet Socialist Republic"). These constitutions provided few protections normally considered to be component parts of the rule of law in the western legal tradition and in the constitutions of modern liberal democracies.

Like many elements of the Soviet socialist system, that which remained of UkSSR private law was rigidly structured into various sections, reflected in the existence of codes covering different cognate areas of law, including civil, criminal, family and labour law (Biryukov 56). As is the case in civilian systems generally, these codes were deemed to be the primary source of law, although judges of the higher Soviet courts tended to expect their judgments would be treated as binding precedent, in a manner similar to the doctrine of stare decisis in a common law system (Lehman 195).

\section{POST-INDEPENDENCE}

Following the declaration of independence in 1991, the Parliament of Ukraine was tasked with determining how the country would be governed, including the laws and regulations that would form the legal system of this newly independent state. Commentators note that the means of Ukrainian independence resulted in a post-independent state that was in many ways very similar to the UkSSR (see Subtelny; Biryukov). Without the impetus for change that other Soviet states experienced through their revolutionary moment, and without violence or revolution to dislodge the Communist elite, the method of independent governance was simply business as usual (Subtelny 603). While a number of changes were quickly made to legislation to reflect Ukraine's sovereignty (Lehman 191), the fact that the Parliament consisted mainly of communist era nomenklatura meant that there was little incentive to introduce meaningful reforms, and those 
reforms that were introduced were poorly implemented (Subtelny 592); as such, independent Ukraine simply retained the legal system and institutions of the UkSSR (Lehman 191). Writing in 2000, Christopher Lehman noted that the legal system inherited by the immediate post-Soviet Ukraine was full of "flaws and idiosyncrasies [and] proved remarkably resistant to change" (191).

Still, while the initial prospects for reform seemed poor-legislative reforms lacked a clear vision, often involved apparently arbitrary and poorly thought out amendments to existing law and were inadequately enforced-the reform process gained momentum. Economic crises in the early 1990s provided the incentive for the government to move away from Soviet economic and social policies and, by 1996, Ukraine had successfully introduced a new Constitution, leading then President Kuchma to declare that Ukraine's state-building process was "complete" (Subtelny 605).

Described as a "blueprint" for Ukraine (Wolczuk 228), the 1996 Constitution signified a new respect for the rule of law and a clear statement of Ukraine's desire to become a "democratic, social, law-based state" (Constitution, Preamble), setting out the framework for an independent Ukraine. Kataryna Wolczuk argued that the Constitution finally established three essential parts of the Ukrainian state: the political community; the institutions, rules and procedures that constituted the state; and importantly, the new "socio-economic profile and goals of the state." By including rules relating to private property and describing the relatively limited role of the state in dictating socio-economic relations, the constitution was clearly a step towards more western economic and legal systems (see also Rezie 169). And while it protected many economic and social rights, criticized as unenforceable remnants of Soviet socialism (Opinion on the Constitution of Ukraine), the Constitution generally marked a new stage in Ukraine's transition from a socialist state, covering (i) rights, freedoms, and duties of individuals and citizens; (ii) elections and referenda; (iii) executive and legislative governance; (iv) the procuracy; (v) the justice system; (vi) the territorial structure of Ukraine and the Autonomous Republic of Crimea; ${ }^{1}$ (vii) local self-government; and (viii) the Constitutional Court of Ukraine.

Yet, while the Constitution attempts to include the social and economic rights found in the Soviet socialist ideals of the role of the state (Rezie 179),

${ }^{1}$ How this part of the Constitution operates in the context of the ongoing annexation of Crimea is unclear. 
the Council of Europe Venice Commission described the inclusion of these rights as a "political compromise" (Opinion on the Constitution of Ukraine 13). Social inequality, poverty and lack of housing in Ukraine today indicate that the Soviet ideology that insisted upon constitutionalizing such rights may be losing real force in an increasingly unstable state. We will return to this theme in considering the consequences of introducing private property in post-Soviet Ukraine.

\section{JUDICIAL REFORM AND THE COURTS}

As part of the reforms made to the Ukrainian legal system, the 1996 Constitution established an independent Ukrainian judiciary (art. 126) and set out in broad terms the role of the courts and judges in the administration of justice (chapter VIII); art. 124 of the Constitution explicitly provides that "[j]ustice in Ukraine is administered exclusively by the courts." Laws on the judiciary introduced in 2001-02 elaborate upon the Constitutional provisions, setting out with greater specificity the principles and procedures of the judicial process (Biryukov and Shyrokova 12). In 2005 , the government announced further reforms to the judiciary, with the aim of strengthening the rule of law and democracy in Ukraine (Tiede and Rennalls 97).

Today, the Ukrainian judicial system is primarily comprised of a number of courts of general jurisdiction; the general jurisdiction of Ukrainian courts "extends to all legal relations that arise in the State" (Constitution art. 124). Article 125 of the Constitution establishes the Supreme Court as "the highest judicial body in the system of courts of general jurisdiction." The Supreme Court has appellate (cassation) jurisdiction in respect of all general courts and the power to refer questions of Constitutional law to the Constitutional Court (Biryukov and Shyrokova 16). Below the Supreme Court sit a number of other specialized courts, including the Higher Economic Court of Ukraine and the Higher Administrative Court of Ukraine. Two options exist in relation to appellate courts: The Cassation Court of Ukraine, which reviews the "lawfulness" of court decisions, that is, whether the law has been correctly applied, and Courts of Appeal. There are both general (which are territorially divided) and specialized courts of appeals, such as of economic or administrative law. The lowest courts in the Ukrainian court hierarchy are the local courts, which include district (raion) courts, city courts, local military tribunals and regional economic courts.

The Constitutional Court of Ukraine is a key component of the Ukrainian judicial system. As with Constitutional Courts of western European states (Biryukov and Shyrokova 11), the Ukrainian Court is not part of the judicial hierarchy, but acts as the sole Ukrainian court with 
jurisdiction to decide on issues of constitutionality of Ukrainian laws and executive action. The Constitutional Court of Ukraine also has the judicial power to interpret the Constitution of Ukraine (art. 124). The power of the Constitutional Court is drawn firstly from the Constitution of Ukraine and supplemented by the Law of Ukraine No 422/96-BP On the Constitutional Court of Ukraine of 1996. To formally ensure the independence of the Constitutional Court from the three arms of Ukrainian government, responsibility for appointing the 18 judges of the Constitutional Court is divided equally between the President of Ukraine (for the executive), the Verkhovna Rada (for the legislature) and the Congress of Judges of Ukraine (for the judiciary). Decisions of the Constitutional Court are final and binding throughout Ukraine.

Yet, despite these reforms, the judicial system remains an underdeveloped element of the Ukrainian legal system. In 1999, Kim Ratushny wrote that

[d] espite constitutional pronouncements, despite Western aid and advice, and except for some promising decisions recently in the new Ukrainian Constitutional Court, progress has been slow in reforming the Ukrainian judiciary to conform with Western notions of an independent judiciary. (568)

Similarly, in 2000, in the context of considering essential bail reforms in Ukraine, Christopher Lehman described the difficulty experienced by the judiciary in ensuring their independence from the state and the procuracy (Lehman 194); the lack of juries, too, despite a constitutional right to a jury trial, has also been discussed as an impediment to Ukraine's transition to a democratic state (Sheyn 649).

Further, a 2000 Report written by Transparency International and the Ukrainian National Integrity System found that perceived and actual corruption and bias pervaded the judiciary and, further, that despite Constitutional provision to ensure an independent judiciary, judges are seen as lacking independence and integrity (Kokhan; Khmara). A 2011 study on corruption in Ukraine confirmed this perception, finding that "the judicial system, the law enforcement system, and the operations of the police might still be influenced by the wrong principles established during Soviet times and during the first years of independence" (Kokhan 2; see also Tiede and Rennalls). Inadequate resourcing of the courts only compounds and exacerbates the perception of and potential for bias; the courts are under-resourced, thus resulting in a susceptibility to bribery and corruption, further compromising judicial independence and raising concerns about access to justice (Biryukov and Shyrokova 11). 
And while perception and resourcing might be overcome with the necessary will to do so, the social and political instability in Ukraine, from the Orange Revolution in 2004 to the 2013 Euromaidan and continuing tensions in Crimea and with Russia, make the enactment of effective and necessary legal reform difficult if not impossible to achieve. Where writers in the late 1990s and early 2000s expressed some optimism about Ukraine's future, and despite apparently positive and popular changes in leadership resulting in stronger relationships with western Europe, Ukraine's legal system is still riddled with inadequacies.

It appears, therefore, that despite the introduction of theoretically sound provisions establishing the judiciary, political, social and economic circumstances inhibit its operation in accordance with the rule of law (Biryukov and Shyrokova 11). Ukraine's unique transition to independence lacked the determination and real change necessary to establish an effective new state. True, reforms and new legislation continue at pace; ${ }^{2}$ yet, without significant overhaul of the inconsistencies between legislative instruments and the poorly functioning judicial institutions, Ukraine's legal system continues to falter.

\section{Civil Code}

1. SOVIET

Although the Soviet Union eliminated most private law following the creation of the UkSSR, in 1963, the Ukrainian Supreme Soviet introduced a Civil Code, typically the primary vehicle used by civilian systems to establish private law. Still, rather than a distancing of the UkSSR from the USSR in the nature of the two legal systems, the structure and content of this code was determined by the central USSR government and was based upon the 1961 Principles of Soviet Legislation (Biryukov 64).

The 1963 Code, then, established rules related to private law, such as property and inheritance, but did so from a socialist ideological perspective. Thus, while on the one hand the Code regulated familiar private law areas such as contract law and secured transactions (Biryukov and Shyrokova 67), on the other, it introduced the management of state-owned property, enforced the prohibition on private property and restricted civil rights (Kossak 87; Biryukov 53).

The 1963 Code, in providing for a centrally planned economy, stopped short of the calls of some Soviet scholars for a parallel Economic Code

2 See the website of the Verkhovna Rada for up to date listings of new Ukrainian Legislation: <http://zakon4.rada.gov.ua/laws/main/en/annot>. 
which would limit government regulation and administration of the economy (Biryukov 63-64). The 1963 Code therefore played a dual role as source of both legal and economic regulation.

\section{POST-SOVIET}

As previously noted, Ukraine's transition to independence in 1991 came with no accompanying political incentive or will to reform the socialist legal system of the UkSSR. As such, rather than set about drafting a new civil code, the Verkhovna Rada opted to amend the existing 1963 Civil Code as necessary, while simultaneously implementing new pieces of legislation so as gradually to transition Ukraine away from failing socialist legal institutions and models and towards western constructs of private law.

It should come as no surprise that this piecemeal process of reform, violating the fundamental principles of consistency in legislative drafting in a civilian system (Steiner 14-23), resulted in numerous inconsistencies not only between provisions of the amended 1963 Code itself, but also between the Code and other legislation enacted by the Verkhovna Rada; socialist terminology and ideology was not uniformly removed, leading in turn to uncertainty in application and implementation.

Moreover, given the chaotic nature of the new Ukrainian legal system and its judiciary, this legislative imprecision has only served to exacerbate concerns of corruption and inefficiency. As such, by the late 1990s, the 1963 Code no longer presented an accurate codification of private law in Ukraine and, indeed, no such codification existed to facilitate access to the law and to justice. The failure of the reform process led to frequent calls for the need to adopt a comprehensive civil code (Biryukov 58).

Thus, in 2001, the Verkhovna Rada began the process of drafting a new Civil Code for Ukraine. It was intended that a new Civil Code would modernize Ukraine's private legal system, implement free-market principles and comply with Council of Europe specifications so as to improve Ukraine's relationship with the West (Biryukov 53). Crucial to this was the desire to increase foreign investment in Ukraine in order to support its fragile economy-without predictable and enforced private law regulations foreign companies were reluctant to invest in Ukraine (Shiskin and Drobyshev 43). By 2003, the drafting process was complete. On 16 January 2003 the Verkhovna Rada enacted the Civil Code of Ukraine (the 2003 Code), ${ }^{3}$ which came into force on 1 January 2004.

${ }^{3}$ See Butler for the English translation of the Civil Code used in this article. 
The 2003 Code consists of six books covering all aspects of private law in Ukraine: (i) General provisions; (ii) Personal non-property rights of a natural person; (iii) Ownership rights and other proprietary rights; (iv) Intellectual property rights; (v) Law of obligations; (vi) Law of succession.

The General Provisions of the 2003 Code set out the parameters of the Ukrainian civil legislation and established some fundamental concepts of the civil law, including definitions of natural and juridical persons, civil rights, how transactions are effected and periods of limitation. This first book also sets out the economic societies of Ukraine and how the Ukrainian State, the Autonomous Republic of Crimea and the Territorial Hromadas are to cooperate (Butler 55-57).

The personal non-property rights set out in the second book read, at times, like social and economic human rights-the rights to medical assistance, family and an environment safe for life and health (Butler 85, 88 [arts. 284, 291 and 293]) —and, at other times, more like civil and political rights-freedoms of movement and association (Butler 85, 88 [arts. 284, 291 and 293]), and some privacy rights (Butler 86, 90 [arts. 285, 286, 301]). Many of these rights are effectively protected in the Ukrainian Constitution; why they have been reiterated in the 2003 Code is unclear. This is one of the shorter books of the Code, consisting of only 3 chapters.

The third book begins by setting out the substance of the right of ownership in Ukraine (Butler 95 [art. 316]). This includes how property rights are acquired and lost, the existence of common ownership rights, and how one's ownership rights may be lawfully defended. Subsection II of this book then sets out rights to "things in another's property." In essence, these laws deal with the situations where a non-property owner may have a right to use, or an interest in, another property, for example, the rights of land users who have a contract with the land owner. This "right to use of another's property" is understood in the Ukrainian legislative context as a "servitude" (Butler 118 [art. 401]). Such prescriptive legislation may appear unfamiliar to a western property lawyer, but seems to act as an alternative means of codifying laws relating to property contracts.

Following from the general discussion of proprietary rights, the fourth book deals specifically with intellectual property rights. An intellectual property right is defined as "the right of a person to the result of intellectual, creative activity or to another object of intellectual property right determined by the present Code $^{4}$ or other law" (Butler [art. 418.1]).

${ }^{4}$ Article 420 of the Civil Code sets out a non-exclusive list of objects of intellectual 
Interestingly, under the Code, intellectual property rights exist independently of the right to ownership of the thing that is the object of an intellectual property right; the transfer of a right to ownership of a thing does not correspondingly effect the transfer of a right to intellectual property in that thing, and vice versa (Butler [art. 418.1]).

The fifth and longest book of the code is titled "Law of Obligations," which are defined as

a legal relation in which one party (debtor) is obliged to perform to the benefit of another party (creditor) a determined action (transfer property, fulfill work, render a service, pay money and so on) or refrained from a determined action, and a creditor has the right to demand performance of his duty from the debtor. (Butler 144 [art. 509.1])

As such, from a western perspective, this book in essence deals with the law of contracts. The first two sections set out the general provisions relating to obligations and contract. The right to freedom of contract is set out by arts. 6 and 627 of the 2003 Code. The third section describes the various types of obligations an individual may legally incur, covering both contractual obligations (including purchase-sale contracts, rental contracts, loans, settlement and joint activities) and non-contractual obligations (including in relation to public competitions, preventing or eliminating harm to or rescuing from harm another person or a person's property and various compensation provisions).

The final book of the code covers the law of inheritance. In Ukraine, inheritance can occur by will or by operation of law (Butler 327 [art. 1217]) - this part of the 2003 Code provides the various laws that govern inheritance and provides the legal framework for effecting the right to inheritance and the execution of wills. Chapter 90 also provides for contracts of inheritance, whereby one party (the acquirer) can contract with another (the alienator) such that (a) the acquirer is obliged to fulfill the instructions of the alienator and (b) in the event of the alienator's death, the acquirer acquires the right of ownership in the alienator's property (Butler 349 [art. 1302]).

In a comprehensive analysis written in 2007, Sergei Shiskin and Pavel Drobyshev concluded generally that, while an "acceptable" piece of legislation, the 2003 Code is problematic in that it inefficiently regulates

property right, including literary and artistic works, computer programs, performances, scientific discoveries, inventions and commercial secrets (Butler 123). 
corporate law and third party rights, excessively details certain regulations (to the extent that they may be unenforceable or of limited application) and imposes barriers to deregulation, preventing the full development of a freemarket economy (Shiskin and Drobyshev 50).

Critics also note that Ukraine introduced a 2003 Economic Code simultaneously with the 2003 Code (see Biryukov 53; Shiskin and Drobyshev 41) and while the latter seemed to be a leap forward towards establishing a free market society with respect for principles of private law and business, the former preserves many elements of Soviet-style planned economies-the antithesis of a free market. Further, there exist many overlaps and inconsistencies between the two 2003 Codes (Shiskin and Drobyshev 53). Such overlap reflects the lack of thought put into the development of this legislation and the power of competing interests in the governance of Ukraine-clearly entrenched powers sought to preserve communist ideals and practice in Ukraine more than 10 years after independence. Still, observers note the lack of enforcement of the 2003 Code (Shiskin and Drobyshev 49), and it seems likely that the increasingly outdated socialist principles in the 2003 Economic Code are equally ignored.

\section{UKRAINIAN PROPERTY LAW}

This Part provides some detail in relation to the place and implementation of private property in the post-Soviet Ukrainian law as found in the 2003 Code. It is well established that private property is a fundamental component of the private law of any state and to the effective establishment of a free-market economy. By examining the adoption, development and implementation (or lack of it) of private property rights since independence, we can see how Ukraine is progressing in its transition to a civil law, free market state. One section considers the Soviet system of state property law, while another considers post-Soviet private property pursuant to the 2003 Code.

\section{SOVIET}

Given that the absence of private property rights comprises one of the fundamental differences between socialist Soviet and capitalist economies, the USSR Civil Code of 1922, which had some effect in the UkSSR, abolished everything connected to private property (Biryukov 56). Yet a modification to the Soviet approach occurred through the introduction of the concept of "operative management" in the 1963 Civil Code of the UkSSR; drawn from the 1961 USSR Principles of Civil Legislation, operative management was 
similar to a private proprietary right, albeit one that did not go so far as to establish private ownership of property (Raff and Taitslin 286).

Over time, three other modifications edged closer to some form of private property in the UkSSR. First, in addition to the novel concept of operative management, the 1963 Civil Code (see below "Right of ownership") provided a number of protections in relation to property, defining the property right as "legally regulated civil relations with regard to ownership, use, and disposition of property" (Biryukov and Shyrokova 35). Second, the 1963 Code declared the possibility of property ownership in the peoples of Ukraine, the citizenry, legal persons and the State (Biryukov and Shyrokova 35). While this declaration appeared to countenance some form of private property, and therefore to conflict with communist ideals, it is unclear to what extent these rights were actually granted or enjoyed by citizens of Ukraine and other legal persons. Finally, the 1963 Code also provided for the enforcement, termination and protection of ownership rights and for some real estate interests (Biryukov and Shyrokova 37-43).

In the absence of a full assessment of the impact of the Soviet system of property law, at least some have argued that collectively owned property caused significant economic damage to the UkSSR and resulted in poor living conditions, inequality and poverty (see, e.g., Bulkina). How, though, has the post-Soviet system of property law in independent Ukraine fared?

\section{PosT-SoviET}

\section{RIGHT OF OWNERSHIP}

As we have seen, in the immediate post-independence era, Ukraine clung to socialist ideals of governance and political organization; few signs of real intent to introduce a non-socialist system in Ukraine emerged, let alone a free-market liberal state in toto. Private property, though, appeared to be an exception to this trend. While other areas of the law developed slowly through amendment to existing legislation and regulations, property law comprised a seemingly "clean slate" (Bulkina 593). Admittedly, this was mostly due to necessity-under Soviet rule, as we have seen, there was little accommodation made for the full private ownership said to be necessary for the effective operation of a capitalist market economy. As the USSR and the UkSSR no longer existed, it became necessary to introduce legislative schemes to provide for private ownership, the bedrock concept necessary for the operation of a capitalist economy.

In one of its first legislative acts, the Verkhovna Rada passed the Law on Property in 1991, followed by a series of laws on privatization of collective and state property, such as the 2001 Land Code of Ukraine (see Biryukov and Shyrokova 35), with the details to be spelled out in subsequent 
regulations. Moreover, the post-independence changes were to be read in the context of the 1978 Constitution of the UkSSR and the 1963 Civil Code, which would have produced contradictions, had implementation been fully achieved. The contradictions between legislation led to issues of access to justice and uncertainty with respect to the private property rights people may have (Bulkina 613).

And the 2003 Civil Code did nothing to clarify the difficulties and contradictions found in the introduction of private property; rather, the reforms implemented overlap with and at times contradict the Land Code of 2001 , resulting in an even more complicated system of rights protection. In the third book of the 2003 Code, the right of ownership is conceptualized as "the right of a person to a thing (or property) which he effectuates in accordance with a law at his will irrespective of the will of other persons" (Butler 95 [art. 316]). This right is perhaps more similar to the absolute right to private property recognized in western states, noting, however, that ownership rights must be exercised in accordance with a law. Article 181 of the 2003 Civil Code, for instance, defines real property ("immovable things") as "land plots, and also objects situated on a land plot whose movement is impossible without reducing the value thereof and changing the designation thereof" (Butler 58 [art. 181(1)]); see also Bulkina 615). "Moveable things" (personal property) are correspondingly defined as "things that can be freely moved in space" (Butler 58 [art. 181(2)]). And a private property owner has "the right to own, use, and dispose of his property as well as defend himself from his rights being violated" (Biryukov and Shyrokova 36). The concepts of "own," "use" and "dispose" are further defined in the Code as:

the right to own is a legally secured possibility of factual possession of a thing; the right to use is a legally secured possibility of the owner to elicit from the owned property its useful qualities to satisfy his own property and non-property needs, and; the right to dispose is a legally secured possibility to determine the fate of an owned thing. (Biryukov and Shyrokova 37)

The 2003 Code further omits the Soviet concept of collective ownership, replacing it with communal ownership, which permits "territorial communities" to become owners. The 2003 Code also assigns property rights more expansively than the 1963 Civil Code, allowing the people of Ukraine, natural persons, legal persons, the State and the Autonomous Republic of Crimea also to own property (Biryukov and Shyrokova 36).

Other sections of the 2003 Code deal with property law indirectly. As discussed above, Book V of the 2003 Code deals with contract law, including contracts relating to leases of land or housing and property management. 
Chapter 79 of the 2003 Code further provides the right to act in respect of another person's property to prevent, eliminate or reduce damage to that property. Chapter 82 then provides for compensation for harm caused to a person's property in a way not unlike that found in relation to common law principles of tortious liability for negligence. Book VI of the 2003 Code also considers the transfer of property rights in the context of inheritance. Article 1225 provides that rights to ownership and use of land and buildings upon land are transferred to heirs upon the death of the owner; this system stands in stark opposition to Soviet property law, where upon a person's death, their property interests were transferred to the Soviet Government (Bulkina 602).

\section{OBLIGATION OF HOLDING PRIVATE PROPERTY}

In all the contradictory protection given to private property, one might wonder about the inherent obligation that comes with holding private property rights. With private property comes the potential for negative outcomes for the private property and personal rights of others and a threat to the social good, and to the very existence of the institution of private property itself (Lametti, "The Concept of Property" 342-347; see also Lametti, "Property and (Perhaps) Justice" 670-672). As time passes and social conditions and relationships change, a right that might once have given its holder legitimate power over a thing may become one that allows that same holder to exert illegitimate power over others in ways that deny those others the same rights to security and autonomy that private property is normally thought to confer (Singer and Beerman 228). This threat exists when we view private property only as a bundle of unchecked and unregulated rights over things held by people living in isolation from others. The failure to limit those who hold private property permits them unilaterally to alter the status of everyone else in society by involuntarily imposing, amending, or eliminating duties not to interfere (Lametti, "The Concept of Property" 346-347).

In order that a system might strike a balance between individual wellbeing and collective social good therefore necessitates, indeed requires, monitoring, or regulation. This is the community's ability to control and alter the scope of private property rights over time as their social meaning changes. If private property were unfettered, as social conditions and relationships change, it runs the risk of producing negative social outcomes for many people and, ultimately, of cancelling itself out altogether (Lametti, "The Concept of Property" 346-348; see also Lametti, "Property and (Perhaps) Justice"). Over time, regulation preserves private property rights within a context of relatedness to others, thus protecting others against harmful outcomes (Singer and Beerman 228). David Lametti says that 
[s]ince private property by definition entails scarcity, and since by allocating the resource through a private property regime to individuals will create inequality, it is thus entirely justifiable and understandable that the institution will come with strings attached. Private property must in some way serve some greater good in order to be justified. While definitely important, the promotion of individual autonomy cannot persuasively stand as the sole reason justifying [private] property rights. Some others goals, including collective ones, must be served. The analysis is ... expressly moral ... in that the goals served are more clearly moral and certainly more plural and complex. (Lametti, “The Morality of James Harris's Theory of Property" 154)

Thus, the goal of private property ought to achieve a balance between the individual and the collective, which in turn means that rights-because they exist within a network of social relationships-must and do come with, as Lametti says "strings attached," or, in other words, obligations manifested in regulation (Singer 205-206). In short,

Owners have obligations; they have always had obligations. We can argue about what those obligations should be, but no one can seriously argue that they should not exist. (Singer 18)

In long-established legal systems, the obligations of private property develop organically as regulation achieved through the long accretion of case law, legislation and social and policy norms. Ukraine's system, however, emerging from a socialist past with no familiarity with private property, was cut from whole cloth. Legislative enactments conferred upon Ukrainians the private property rights that might in systems such as the United States' have developed over a much longer period of time. In the absence of organically-developed inherent regulation, then, Ukraine simply created it, along with private property itself, in the Constitution (arts. 13, 14 and 41) and the Land Code (arts. 1.2, 1.3, 78.1, 78.2 and 91). Rather than wait for the slow accretion of case law, legislation and social and policy norms that we see in the longer-established western systems, Ukraine's legislators, working from models of private property derived from those western countries that assisted Ukraine in the process of privatizationSweden, Canada, the United States, Belgium, Denmark, and representatives of the World Bank (Bondar and Lilje 1, 7-8)-explicitly imposed them as part of the private property right. 
Ukraine's land law, comprised of the Constitution ${ }^{5}$ and Land Code 2001, provides an example of the way in which obligation was created through Ukrainian land law. Together, the Constitution and the Land Code 2001 establish a basic private property right in land. The former guarantees the right to own, use and dispose of property, the right not to be unlawfully deprived of the right to property, and proclaims inviolable the right to private property (art. 41). The Land Code 2001 defines private property in land as "... the right to own, use, and dispose," which equips the holderwho may be either a citizen or a legal entity (arts. 78.3 and 80.a; and see arts. 22.4, 81.2 and 82.2) -with the rights to sell, give, exchange, bequeath, lease, and mortgage, and to use the natural resources, own all crops raised, and erect buildings thereon (Land Code art. 90.1; see also Bondar and Lilje 9-10). This represents an important step towards the establishment of private property rights. Until the introduction of the Land Code 2001, the only persons who could own private property in Ukraine were natural persons who were Ukrainian citizens. Together, then, the Constitution 1996 and the Land Code 2001 "constitutionalize" the right to private property (see Alexander), establishing a straightforward definition with which most westerners would be more or less familiar. And this opened Ukraine to external investment and established a more comprehensive system of property ownership (Biryukov and Shyrokova 39-40).

Yet, on closer inspection, both reveal something that may seem less familiar to westerners, but which is no less known in their legal systems. Article 13 of the Constitution, for instance, provides that "[p]roperty entails responsibility. Property shall not be used to the detriment of the person and society." Article 14 reads: "[t]he right of property to land is guaranteed. This right is acquired and realised by citizens, legal persons and the State, exclusively in accordance with the law." And art. 41 establishes that "[t]he use of property shall not cause harm to the rights, freedoms and dignity of citizens, the interests of society, aggravate the ecological situation and the natural qualities of land." The Land Code 2001 contains similar language. Article 1.3, for instance, says that the "[u]se of land property shall not harm citizens' rights and freedoms, [the] interests of society, [nor] worsen [the] ecological situation and [the] natural properties of land." And art. 91 provides that:

5 For a background to Ukrainian Independence and the Constitution of Ukraine 1996, see Subtelny (573-632), Diuk (8-18), and Plokhy (291-346). 
1. Land plot owners are obligated to:

a. ensure that land is used in accordance with its designation;

b. comply with environment legislation;

c. timely pay land tax;

d. not violate the rights of owners of adjoining land plots and land users;

e. increase the fertility of soil and preserve other utile properties of land;

f. timely submit to the appropriate bodies of executive power the data on the state and utilization of land and natural resources in the manner established by law;

g. observe the rules of good-neighborhood and restrictions related to the establishment of servitudes and protected zones;

h. keep geodesy signs, anti-erosion structures, irrigation grids and drainage systems.

2. The law may establish other obligations of land plot owners.

To many westerners, steeped in the lore of individual autonomy and freedom from interference-both state and that of others-such provisions may appear nothing like the private property with which they are familiar. For them the language of obligation, responsibility, the rights of others, the interests of society, good-neighbourhood, and protecting the ecological situation and the natural qualities of land is nothing more than socialism or communism in disguise. It is hardly capitalism founded upon the bulwark of private property. Seen from this perspective, private property and its protection of individualism, freedom and autonomy, brings with it the preference satisfaction, or self-seekingness, or self-regarding behaviourthe ability of the individual who holds private property rights to exercise them in any way they choose, unfettered and without regard to anyone else-that forms the core of western democratic capitalist systems.

Yet, any understanding of private property which emphasizes the primacy of autonomy and freedom in this way is a chimera-it is not the reality of a working system of private property, including western deployments of that concept. Any such system contains limitations that restrict the way in which its private property rights are characterized and allocated, and the way in which those who hold those rights can exercise them. In other words, as Joseph William Singer says, "[e]ven the most rudimentary property system requires substantial regulation to answer questions about the allocation and scope of property rights" (78). And while one might not agree with Singer's political philosophy, one cannot but agree that even American private property-often considered at the vanguard of individualism and autonomy-is awash in a sea of regulation. 
From this perspective, then, Ukrainian land law may be much more like a western system of private property than first appearances suggest. In fact, although there is a paucity of historical information which explains its origins, ${ }^{6}$ on reflection, Ukraine's land law is neither socialist, communist, nor, for that matter, particularly innovative; rather, it seeks to regulate the allocation and scope of private property rights in land, which is the hallmark of long-established, "mature," private property systems such as the United States'.7 In other words, it "constitutionalizes the social obligation" of the private property right (see Alexander 97-197), differing from a system like the United States' only in that its regulation is patently obvious and found in a small and rudimentary legislative "code." The United States has in fact much more regulation than does Ukrainian land law, although to find it one must look very closely at a complex accretion of case law, legislation and social and policy norms developed over a long period of time (Singer 78-79).

So how successful has post-independence Ukraine been in striking the balance between the individual and the collective in its implementation of private property with imposed obligation? The next part turns to that question.

\section{POST-INDEPENDENCE OUTCOMES}

From what we have seen, there is little doubt that the former UkSSR has experienced substantial growing pains in the attempt to adapt to postcommunist, market-based capitalism (see, generally, Varese). Michael Heller's coining of the phrase and the development of the concept of "anti-

6 This conclusion is based upon correspondence and conversations over 2004-2006 with Vlad Vernygora, a Ukrainian lawyer, who advises that law generally is one of the least developed and under analyzed aspects of Ukraine's history since independence in 1991. In a personal e-mail dated 14 July 2006 (on file with the author), Mr. Vernygora wrote: "The main explanation for the lack of literature and documents related to that part of the historiography (it can be described either as 'historical aspects of the constitutional provisions' or 'legislative aspects of history') is that the whole constitutional process in Ukraine was not as transparent as the West understands transparency. That is why it is always hard to get to the depth of the issue and answer the question: 'Why did they end up with this particular formula, but not with the other one?"'

7 Other former Soviet states have done the same thing. In the case of Russia, for instance, the change to a market economy and its concomitant modification came in rapid stages (Sukhanov 301; see also Amsden, Kochanowicz and Taylor). 
commons property" followed a walk down a Moscow street ("Critical Approaches" 423-24; "The Tragedy of the Anticommons" 622-23). Other post-Soviet states have faced similar obstacles in the transition from public to private property. Indeed, for many in the former USSR, the cruel reality is that private property has operated to impoverish rather than liberate, create instability rather than certainty.

This part explores four outcomes of the attempt to implement private property in the former UkSSR: poverty, corporate raiding, property tax, and the state register of proprietary rights. Each of these outcomes, in their own way, demonstrate not only the failure of the establishment of private property, but also, and more alarmingly, of the attempt to create regulation without any prior experience with it in the context of a concept of private property.

\section{POVERTY}

Poverty-a negative social consequence of self-interested exercises of private property rights-is representative of the range of typical negative social outcomes that may stem from private property and may recur in any system. Even prior to independence in 1991, Ukraine was already in economic decline. And following the collapse of the USSR, four problems faced the newly independent Ukrainian government: (i) the removal of the larger Russian economy as the main, if not exclusive market for Ukrainian products; (ii) the elimination of former Soviet republics as suppliers of raw materials or finished products necessary for the production of goods in Ukraine; (iii) increased energy costs, which, under communism, had been kept artificially low; and (iv) the ongoing impact of the Chernobyl nuclear disaster (Subtelny 619). The fact that the major players who presided over the collapsing Soviet economy were the same ones charged with transforming Ukraine's into a market economy following independence only served to exacerbate the impact of these problems. Within the new government, different views proliferated about the appropriate and necessary policy to direct the shift from communism to capitalism (Subtelny 619-24). But as Subtelny says, whatever method was chosen, putting the old guard in charge was

comparable to engaging Wall Street "sharks" to transform a capitalist economy into a communist one. Obviously, most of the new/old Ukrainian elite had neither the will nor the ability to introduce effective economic reforms. And if it did introduce reforms, they were usually ones that served its own interests. (619)

In this economic environment, the move to establish private property in land, therefore, conferred decision-making authority upon Soviet-era 
oligarchs, empowering them to effect prykhvatyzatsiia-a rapacious privatization, or literally privatization by seizure. This occurred in various ways: some simply transformed Communist party funds and property into private holdings; others took advantage of monetary policy to reap huge profits which were used to purchase entire industrial sectors; while still others purchased cheap raw materials and then obtained hard to come by export licenses to sell them on the world market (Subtelny 621). In every case, government connections were more important than capital in obtaining private property, resulting in the

rapid transformation of the most intrepid members of the old Soviet nomenclatura into incredibly wealthy oligarchs. However, unlike the robber barons of early capitalism, these new "captains of industry" acquired their wealth by undermining rather than expanding the economy. (Subtelny 62122)

Such unfettered self-seeking exercises of the newly conferred private property merely exacerbated the endemic poverty that was already evident in the late Soviet era. Rather than correcting an existing problem, private property in land had quite the opposite effect-bloating an already serious poverty among a growing unemployed and indigent population. According to Subtelny "[s]tatistics provide only a pale approximation of the depressing reality" (589), although the statistics were depressing enough: in 1992, Ukraine's economy contracted by 20 per cent while inflation skyrocketed by 2500 per cent (589 [citing Financial Times 27 January 1993]). Between 1991 and 2000, the county's GDP had sunk over 63 per cent, one of the worst declines in the former USSR, and the standard of living plummeted to the point where about 70 per cent of the population were close to or below the poverty line (Subtelny 618).

This appalling state of affairs spread unchecked notwithstanding that the Constitution 1996 and the Land Code 2001 clearly aimed at preventing such outcomes. As we have seen, both require that "the use of property shall not cause harm to the rights, freedoms and dignity of citizens, the interests of society" (Constitution art. 41; Land Code art. 1.3). The difficulty, as with all such constitutional provisions, is that the limitations placed on private property by these legislative enactments are nothing more than broad exhortations. Neither document spells out the specific obligations, duties and imperatives required of the holder of private property, nor do they provide for an enforcement mechanism for non-compliance with those 
hortatory words. ${ }^{8}$ Thus, by themselves, while they established private property, they could and can do little to prevent the exacerbation of serious social problems such as income inequality. The construction of exclusive housing estates perhaps best exhibits this trend in Ukraine. Fig. 1 provides a powerful visual metaphor for the state of Ukrainian property law-from the outside these houses appear solid, rational, coherent, and effective. Yet, on closer examination the face of the law is just that, a façade, for not only is the interior inaccessible and unstable, it is completely empty. This property development near Vozdvyzhens'ka street (known as Vozdvyzhenka or Vozdvizhenka), in Kyiv, which, while appearing lavish, sits entirely empty, a ghost town surrounded by poverty, a powerful metaphor for the state of Ukrainian private property law and its consequences for most Ukrainians.

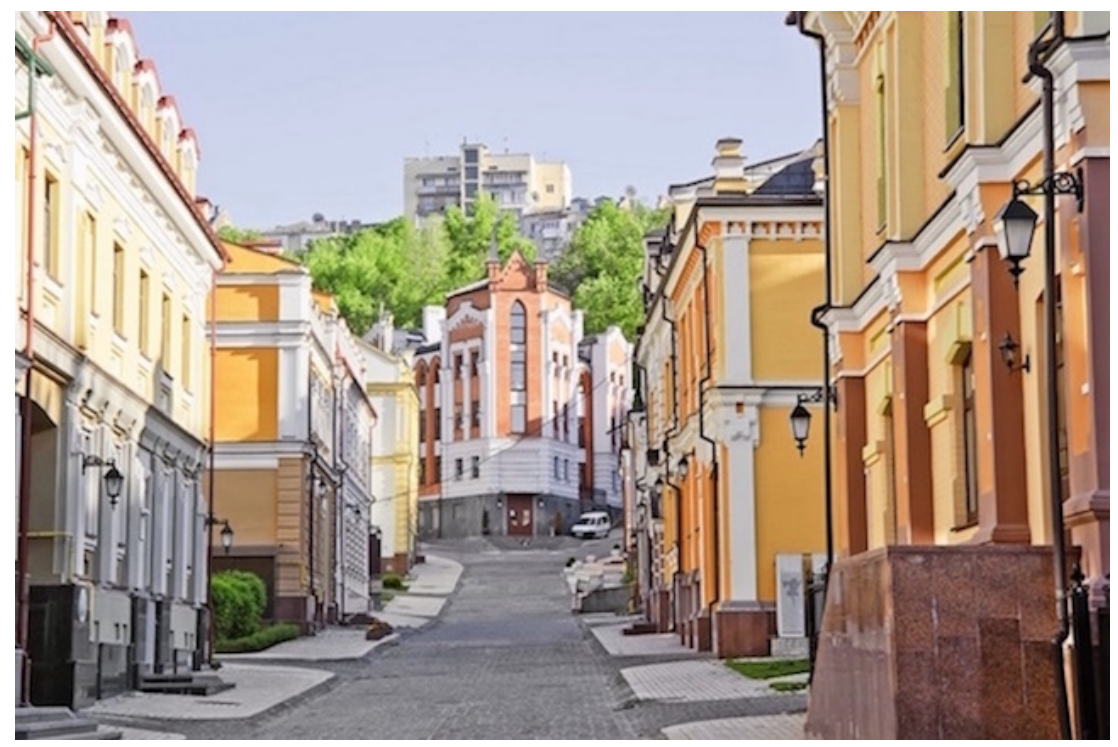

Fig. 1 Vozdvyzhenka District, Kyiv, Ukraine. Source: Dreamstime.com

8 The Land Code of Ukraine specifies numerous penalties for breach of good neighbourliness or environmental harm (chs. 17, 18, 26-28, and Section VIII), although there is no mention of the consequences for failure to comply with the requirement not to harm the rights, freedoms and dignity of citizens and the interests of society. 
And poverty is but one dimension of the problem; on the hill overlooking this ghost estate one can see high-rise housing for impoverished residents of Ukraine, looking down on what might have been their wealthy masters, if only they were there. The lack of regulation which might have alleviated the poverty suffered by those who live on the hill (see Ziff 73-77) also leads to systemic instability and a lack of "actual control" (Munzer 92). In other words, "[i]f burglaries are rampant, the owner's actual ability to exclude others may fall well short of his legal power to exclude them" (Munzer 92; emphasis added). The creation of private property, in the absence of any legally enforceable protection for that right, means that the security normally associated with this institution is lacking. This may result in alternative, usually illegal, means of ensuring control of the resource. Moreover, in the absence of state-sanctioned means of protection of exclusivity, further criminal opportunities emerge as those with property seek to exploit the systemic instability, creating incentives to strip assets, corrupt officials, evade taxes, illegally export capital, and launder money (Varese 36). Indeed, this is the very thing that has happened in Ukraine and in most post-Soviet states (Varese 1-36). This leads in turn to further inequality of distribution of scarce resources, and further poverty.

Thus, in the absence of the monitoring and regulation necessary to prevent unequal holdings and negative social outcomes, even for those with the potential wealth that may flow from private property there is little of the security normally associated with those rights. This produces criminal forms of protection and opportunities for further criminal activity, further inequality and ultimately more crime. These illegal forms of protection and the criminal opportunities that result from a lack of regulation are the informal property and non-property relationships which emerge from formal, legally recognized property, but that we only see when we shift our focus from rights alone to the totality of what is happening in the real world. Vozdvyzhenka provides the visual image of this, while Joseph William Singer, commenting upon Eastern European countries moving from socialist state property to capitalist private property, provides the words:

There is a danger that countries that are attempting to end socialism and are emulating the American market model are basing their public policies on a simplistic ideological fantasy of [private] property rather than the true, complex picture of [private] property under U.S. law. In so doing, they may adopt a form of [private] property that has never existed in the United States and would have had disastrous consequences if it ever had existed. Even the most rudimentary [private] property system requires substantial regulation to answer questions about the allocation and scope of [private] property rights. Jiri Dienstbier, the foreign minister of the former 
Czechoslovakia, commented in 1990 that creating a market economy-a socalled free market-required the drafting of hundreds of regulatory laws. If anything, he understated the problem. (78-79) ${ }^{9}$

Ukraine's poverty is nothing less than a consequence of the failure to provide sufficient regulation to bolster the generalizations found in the Constitution 1996, the Land Code 2001, and the Civil Code 2003. While these enactments may exhort those who hold private property in land to exercise their decision-making power so as not to exacerbate the serious poverty suffered by so many, those landholders who choose to act otherwise face few consequences for doing so.

\section{CORPORATE RAIDING}

In recent years, the phenomenon of illegal corporate raiding, whereby companies (and their property) are illegally seized by unlawful hostile takeovers that are facilitated by exploiting Ukraine's weak property rights protections, and the corruption of Ukraine's legal institutions, has become one of the most prominent examples of the instability of Ukraine's property rights regime. Takeovers involve the use of illegal means-bribery, corruption and blackmail, in turn backed up by the cooperation of corrupt individuals in the Ukrainian judiciary, and by corrupt Ukrainian law enforcement operatives-illegitimately to take control of Ukrainian companies and their property. Paradoxically, this process is both caused by and a source of instability in Ukraine's property rights system (although this may change following the introduction of the State Property Rights Register (see below).

Gábor Zimmerer has usefully divided this practice of corporate raiding in Ukraine into three "colors" of corporate raiders (see also Shmagina and Patsyuk; Rojansky). The so-called "white" raiders "capitalize on the loopholes of the opaque Ukrainian financial regulation system and confusing tax system, but do not violate law by doing this" (Zimmerer 3). They exploit these loopholes by "buying-out the shares of the minority shareholders, buying its extensive debt or re-electing the management" (Zimmerer 2). This type of raiding is technically lawful, but relies extensively on the exploitation of Ukraine's poor legal and regulatory system to take over companies and to seize all of their property and assets. The reality, however, is that white raiders are the least common; Ukraine's

9 It is amazing how closely Singer at $140-141$ captures the very thing that has happened in post-independence Ukraine. 
"complicated bureaucratic system sets huge obstacles in the interactions of governmental agencies and business parties" (Zimmerer 3), which leads raiders to turn to illegal processes to achieve their takeovers.

"Gray" raiders are far more common than the other two types, using "illegal means to foster the processes of gaining licenses, permits, favorable court decision[s] or treatment by authorities" in order to facilitate their hostile takeovers (Zimmerer 3). The most common methods employed by the gray raiders are the seeking out of "biased court resolutions, procuring tax inspections to impair the target firm or sabotaging it's [sic] license granting" (Zimmerer 3). These gray raiders seek to establish an aura of legitimacy to a takeover through reliance on these court resolutions and judgments, procured by bribery or other corrupt practices. This is the most common type of raid, and it is, typically, substantially reliant on corrupt judicial process.

Finally, "black" raiders use "physical violence, threatening, bullying, supplemented by forgery of documents, files, company records and signatures" to deliberately defeat the proprietary interests of owners of the companies targeted (Zimmerer 3).

All three types-white, grey and black-take advantage of Ukraine's weak property rights, and its poor regulatory regimes. The risk of having a thriving business stolen away overnight by these illegal raiders further destabilizes the Ukrainian economy with foreign investors less interested in investing and doing business in Ukraine. The weak protection of property rights results in a lack of willingness on the part of investors to risk investment in businesses with no way of ensuring they remain in control of them. This is particularly so with a corrupt judiciary actively supporting and facilitating these illegal raids-further reducing any chance of recourse by legitimate business owners seeking to regain control of their companies.

\section{PROPERTY TAX}

Many people, walking through Ukraine's beautiful capital of Kyiv, will have noticed its many ancient buildings that sit empty, not unlike the new housing development in Vozdvyzhenka, slowly falling into ruins. One of the main reasons that these buildings stand alone and dilapidated, as highlighted by Brian Bonner, is the absence until recently of any property tax in Ukraine. Despite the adoption of private property, Ukraine failed until recently to levy any property taxes; this is nothing less than another dimension of the failure adequately to provide for the regulation of private property.

Most of the decaying buildings are owned by people who do not use them at all, and the absence of property tax has long meant that the rich can buy property in Ukraine without having to pay any tax on it, thus making it 
possible to use private property merely as a means of avoiding tax, resulting in the inefficient use of real property in Ukraine. Levying an ongoing property tax ensures that owners either put their property to good use, or pay for failing to do so. As Bonner suggests, "[s]imply put, property taxes encourage owners to sell properties not in use."

Ukraine introduced a residential property tax on 1 July 2012; yet, unlike most western countries, the tax is based on the number of square metres rather than the value of the relevant land. As Bonner explains:

The property tax law charges an absurdly low rate to homeowners on the basis of square meters, not on the value of the property. That means that the owner of a 250-square meter shack gets hit as much as the owner of a luxurious apartment of the same size, only with a market value of 10 or 100 or 1,000 or even 10,000 times more than the shack. Moreover, commercial properties remain exempt.

Ukraine's failure to adapt its financial systems to the adoption of private property has therefore produced great injustice. A handful of oligarchs continue to hold most of the available land in Ukraine with little incentive to dispose of that which they do not currently utilize. While the

concept of private property has been taking root again only for the last 21 years ... The longer these tax injustices linger into the $21^{\text {st }}$ century, the worse the nation's financial future will be-and the more grand cities like Kyiv and Kharkiv and Odessa will look like urban ghettoes. (Bonner)

StATE REgister of Proprietary Rights

The final consequence flowing from the introduction of private property in post-Soviet Ukraine represents one of the few positive notes, albeit its need points to an underlying problem. And the length of time it has taken to address this demonstrates how far Ukraine still has to go before its conversion from Soviet to post-Soviet law, especially in relation to private property, can be considered anything like a success.

From 1 January 2013, Ukraine introduced a law to establish a State Register of Proprietary Rights and Encumbrances over Real Property (the Register) ("Law No. 1952-IV"). ${ }^{10}$ This new system has been hailed as a

10 This law, dated 1 July 2004, came into force 1 July 2013. This translation of the original Ukrainian title (ЗАКОН УКРАЇНИ Про державну реєстрацію речових прав на нерухоме майно та їх обтяжень) is from Portnoy. A copy of the legislation, with a slightly different translation of the title, is available at $<$ http://faolex.fao.org/>. 
comprehensive reform in the field of registration of proprietary rights and encumbrances over real property; that has been implemented by the Ukrainian government in recent years to harmonise the system with EU standards. (Portnoy)

The law establishes the Register for all existing property rights and encumbrances, replacing four pre-existing registers: The Register of Ownership Rights to Real Property; the Unified Register of Prohibitions of Alienations of Real Property; the State Register of Mortgages; and, the State Register of Encumbrances over Movable Property.

This system has three primary effects. First, it centralizes the recording of private property rights by creating a State Registration Service to administer the Register, assisted by selected notaries (Portnoy). Second, new property rights "come into existence at the time of their state registration"; pre-existing property rights remain effective, while future dealings require registration (Portnoy). This is a sophisticated system of title by registration, bearing some resemblance to a Torrens Title system. Finally, it will limit the number of individuals who can register rights on the state register.

This new system of title by registration, coupled with a centralized administrative body, should eventually assist in the stabilization of private property rights in Ukraine, helping, for instance, to reduce the phenomenon of illegal corporate raiding. Still, while it has the potential greatly to improve private property rights (and property security) in Ukraine, its ultimate effect remains to be seen given the events of the Euromaidan and subsequent involvement of Russia in Eastern Ukraine in 2014 and 2015 (see Kozloff).

\section{CONCLUSION}

The events of the Euromaidan bring us full circle. I began this article by recounting the excitement with which the Orange Revolution had been met in Ukraine, only to have those hopes dashed through ongoing corruption in government and control by Soviet-era oligarchs. The events of Euromaidan, a decade later, have produced a similar result: great excitement and hope for the future after ten years of stagnation, only to be met with yet another, and much more dire outcome, casting real doubt on the ability of Ukraine ever to transition away from its erstwhile Soviet political status, let alone navigate the move from Soviet to post-Soviet law.

The contradictions between the tone of the Constitution 1996, the Land Code 2001 and the Civil Code 2003 and the legal reality reveals the simple truth about Ukraine's current legal system: the practice of simply creating new laws to address deficiencies and adjust to the ideologies of the state 
results in incoherent and dysfunctional legislation. This in turn leads to further unrest, as we observe in Ukraine today. Although it has made numerous legislative attempts to transition Ukraine to a civil law state and rid itself of its socialist past, much of the problematic terminology, ideology and institutional dysfunction remains. The introduction of a civil code, as well as numerous subsidiary codes appears to have done little to introduce the rule of law to Ukraine and ensure widespread access to justice. Rather, the haphazard and at times chaotic way in which legislation has been introduced and amended has prevented independent Ukraine from developing and arguably led to further instability and violence.

In 2000 Wolczuk wrote with wonderment that Ukraine had avoided the violence that often accompanies such rapid transitions, citing the weak and fragmented polity as the reason for this (124). This proved a short-lived optimism, as has so much previous optimism in Ukraine; the opening years of the $21^{\text {st }}$ century have been marked by significant, ongoing, and escalating violence. Perhaps this is because Ukraine never had the extreme shift associated with most other revolutionary transitions. Though it is probably mere coincidence, it must be noted that the Orange Revolution of 2004 began just months after the introduction of the 2003 Civil Code; if the coming into effect of that law was the transition Ukraine was waiting for, it has most certainly been a rough and painful experience.

And, in all of this, the ongoing barriers to Ukraine's effective transition remain. Widespread corruption continues to be an issue amongst the legal institutions in Ukraine. In the midst of instability and conflict, reforming and consolidating Ukrainian legislation and regulations does not appear to be a priority. The political and economic conditions in Ukraine also reflect a lack of proper implementation of the laws that have been enacted. Accusations of illegal behaviour by police and members of parliament during Euromaidan, and the apparent lack of accountability since then suggest that some if not many Constitutional rights are not being protected. And even if such reform was achieved, in the face of the informal "rules of the game," the "law of the jungle" that governs so much of the operation of private property in Ukraine, the formal law may stand little chance of achieving much at all.

Moreover, a significant barrier to accountability and openness in transition is the inaccessibility of information about Ukraine. For a nonUkrainian speaking outsider, finding up to date information about the Ukrainian legal system is nearly impossible-for all Ukraine's reforms to attract free market external investment, the dearth of information about Ukraine's property laws, both formal and informal, stands as the greatest threat to real transition from a socialist to a capitalist economy. 
Yet, perhaps a glimmer of hope can be found in the ongoing relationships between Ukraine and the European Union. The events of Euromaidan and the subsequent leadership changes have indicated the Ukrainian peoples' will to join the EU. To do so will require rectification of some of the inadequacies of the Ukrainian legal system and a continued, real respect for the rule of law. As long as Ukraine continues to pursue EU membership, the transition towards an effective and stable civil law system may hold some promise.

\section{Works Cited}

Alexander, Gregory S. The Global Debate Over Constitutional Property: Lessons for American Takings Jurisprudence. Chicago: Chicago UP, 2006. Print.

Amsden, Alice H., Jacek Kochanowicz, and Lance Taylor. The Market Meets Its Match: Restructuring the Economies of Eastern Europe. Cambridge MA: Harvard UP, 1994. Print.

Åslund, Anders and Michael McFaul. Revolution in Orange: The Origins of Ukraine's Democratic Breakthrough. Washington: Carnegie Endowment for International Peace, 2006. Print.

Babie, Paul. "The Spatial: A Forgotten Dimension of Property." San Diego Law Review 50 (2013): 323-382. Print.

---. "Two Voices of the Morality of Private Property." Journal of Law and Religion 23 (2007): 271-308. Print.

Biryukov, Alexander. "The Doctrine of Dualism of Private Law in the Context of Recent Codifications of Civil Law: Ukrainian Perspectives." Annual Survey of International \& Comparative Law 8.1 (2002): 53-78. Print.

Biryukov, Alexander, and Inna Shyrokova. The Law and Legal System of Ukraine. Huntington, NY: Juris Publishing Inc., 2005. Print.

Bondar, Anatoliy, and Boo Lilje. Land Privatization in Ukraine. International Federation of Surveyors, 2002. Web. 11 Jan. 2016. <https://www.fig.net/resources/proceedings/fig_proceedings/fig_2002/Ts76/TS7_6_bondar_lilje.pdf>.

Bonner, Brian. "Lack of Property Taxes a Massive Blight on Ukraine." KyivPost. Public Media, 2 Aug. 2012. Web. 11 Jan. 2016. <http://www.kyivpost.com/opinion/op-ed/lack-of-property-taxes-a-majorblight-on-ukraine-310957.html>.

Bulkina, Zhanna. "Development of Ukrainian Real Property and Mortgage Law: The American Perspective." San Diego International Law Journal 10 (2009): 591635. Print.

Butler, William E. Civil Code of Ukraine and Law of Ukraine on Private International Law. London: Wildy, Simmonds \& Hill Publishing, 2011. Print.

Constitution of Ukraine (1996) No. 254k/96-VR-28.6.1996

D'Encasse, Helene Carrere. The End of the Soviet Empire: The Triumph of the Nations. New York: Basic Books, 1993. Print. 
Diuk, Nadia. "Ukraine: Situation Analysis and Trend Assessment." Refworld. Writenet, Nov. 2004. Web. 11 Jan. 2016. <http://www.refworld.org/ pdfid/419333064.pdf>.

Foljanty, Lena. "Legal Transfers as Processes of Cultural Translation: On the Consequences of a Metaphor." Social Science Research Network. Social Science Electronic Publishing, 30 Oct. 2015. Web. 11 Jan. 2016. <http://papers.ssrn.com/sol3/papers.cfm?abstract_id=2682465>.

Harasymiw, Bohdan. Post-Communist Ukraine. Edmonton, Alberta: Canadian Institute of Ukrainian Studies Press, 2002. Print.

Heine, Dirk. "Uncovering Acemoglu's Black Box: Why the Contribution of Formal Property Law to Economic Growth Cannot Be Linear but Must Depend on the Development Stage of a Country." Social Science Research Network. Social Science Electronic Publishing, 30 Nov. 2015. Web. 11 Jan. 2016. <http://papers.ssrn.com/sol3/papers.cfm?abstract_id=2695737>.

Heller, Michael A. "Critical Approaches to Property Institutions: Three Faces of Property." Oregon Law Review 79 (2000): 417-434. Print.

---. "The Tragedy of the Anticommons: Property in the Transition from Marx to Markets." Harvard Law Review 111.3 (1998): 621-688. Print.

Internet Encyclopedia of Ukraine. Canadian Institute of Ukrainian Studies, 2001. Web. 11 Jan. 2016. <http://www.encyclopediaofukraine.com>.

Khmara, Oleksii, et al. National Integrity System Assessment: Ukraine 2011. Transparency International, 2011. Web. 11 Jan. 2016. <http:// www.transparency.org/whatwedo/publication/national_integrity_system_asse ssment_ukraine_2011>.

Kokhan, Halyna, and Creative Union TORO Ukraine. UN Convention Against Corruption Civil Society Review: Ukraine 2011. Transparency International, 2011. Web. 11 Jan. 2016. <http://www.transparency.org/files/ content/publication/87-civil-society-review-ukraine-2011.pdf>.

Kossak, Volodymyr. "General Principles of Private Law in Ukraine." Materilien zum ausländischen und internationalen Privatrecht, Volume 50: Private Law in Eastern Europe: Autonomous Developments or Legal Transplants. Eds. Christa Jessel-Hoslt, Rainer Kulms and Alexander Trunk. Germany: Mohr Siebeck, 2011. Print.

Kozloff, Nikolas. "Insider Oligarchs Derail EuroMaidan Revolution." KyivPost. Public Media, 7 Mar. 2015. Web. 11 Jan. 2016. <http://www.kyivpost.com/ opinion/op-ed/nikolas-kozloff-insider-oligarchs-derail-euromaidan-evolution382818.html>.

Kryvonos, Myroslava. "A Research Guide to Ukrainian Law.” International Journal of Legal Information 31.1 (2003): 1-19. Print.

Kuzio, Taras, and Andrew Wilson. Ukraine: Perestroika to Independence. Edmonton, Alberta: Canadian Institute of Ukrainian Studies Press, 1994. Print.

Lametti, David. "Property and (Perhaps) Justice: A Review Article of James W. Harris, Property and Justice and James E. Penner, The Idea of Property in Law." McGill Law Journal 43 (1998): 663-727. Print.

---. "The Concept of Property: Relations Through Objects of Social Wealth." University of Toronto Law Journal 53 (2003): 325-378. Print. 
---. "The Morality of James Harris's Theory of Property." Properties of Law: Essays in Honour of Jim Harris. Ed. Timothy Endicott, Joshua Getzler and Edwin Peel. Oxford: Oxford UP, 2006. 138-165. Print.

Land Code of Ukraine (2001) No 2768-III-25.10.2011.

"Law No. 1952-IV 'On state registration of property rights to immovable property and encumbrances."' FAOLEX. Food and Agriculture Organization of the United Nations, 16 May 2013. Web. 11 Jan. 2016. <http://faolex.fao.org/>.

Lehman, Christopher. "Bail Reform in Ukraine: Transplanting Western Legal Concepts to Post-Soviet Legal Systems." Harvard Human Rights Journal 13 (2000): 191-229. Print.

Markus, Stanislav. Property, Predation, and Protection: Piranha Capitalism in Russia and Ukraine. Cambridge UP, 2015. Print.

Motyl, Alexander J. Dilemmas of Independence: Ukraine After Totalitarianism. New York: Council on Foreign Relations Press, 1993. Print.

Munzer, Stephen R. "Property as Social Relations." New Essays in the Legal and Political Theory of Property. Ed. Stephen R. Munzer. Cambridge: Cambridge UP, 2001. 36-75. Print.

Opinion on the Constitution of Ukraine. Council of Europe, Venice Commission, 7-8 March 1997. Web. 11 Jan. 2016. <http://www.venice.coe.int/webforms/ documents/?pdf=CDL-INF(1997)002-e >.

Plokhy, Serhii. The Gates of Europe: A History of Ukraine. New York: Basic Books, 2015. Print.

Portnoy, Sergiy. "Ukraine: New System of Registration of Proprietary Rights and Encumbrances over Real Property." DLA Piper, 30 Jan. 2013. Web. 11 Jan. 2016. $<$ https://www.dlapiper.com/en/scotland/insights/publications/2013/01/ukr aine-new-system-of-registration-of-proprietar__/>.

Raff, Murray. "The importance of reforming civil law in formerly socialist legal systems." International Comparative Jurisprudence 1 (2015): 24-32. Print.

Raff, Murray, and Anna Taitslin. "Property Rights Under Socialist Civil Law: Looking Back to the Twentieth Century." Law in Eastern Europe: East European Faces of Law and Society: Values and Practices. Ed. William B. Simmons. Leiden: Brill Nijhoff, 2014. 251-306. Print.

Ratushny, Kim. "Toward the 'Independence... of Judges' in Ukraine?" Saskatchewan Law Review 62 (1999): 567-594. Print.

Rezie, Richard C. 0. "The Ukrainian Constitution: Interpretation of the Citizens' Rights Provisions." Case Western Reserve Journal of International Law 31 (1999): 169-210. Print.

Rojanksky, Matthew A. "Corporate Raiding in Ukraine: Causes, Methods and Consequences." Demokratizatsiya: The Journal of Post-Soviet Democratization 22.3 (2014): 411-443. Print.

Sheyn, Elizabeth R. "Foothold for Real Democracy in Eastern Europe: How Instituting Jury Trials in Ukraine Can Bring About Meaningful Governmental and Juridical Reforms and Can Help Spread These Reforms Across Eastern Europe." Vanderbilt Journal of Transnational Law 43 (2010): 649-699. Print.

Shiskin, Sergei, and Pavel Drobyshev. "Ukraine's Civil and Economic Codes." Problems of Economic Transition 50.3 (2007): 41-95. Print. 
Shmagina, Yulia, and Vitaliy Patsyuk. "Raider Appears Out of Nowhere, There's No Way to Escape: Enemy at the Gate." United Legal Group Association, n.d. Web. 18 Apr. 2015. <http://ulga.com.ua/en/cms/raiders_attack>.

Singer, Joseph William. Entitlement: The Paradoxes of Property. New Haven: Yale UP, 2000. Print.

Singer, Joseph William, and Jack M. Beerman. "The Social Origins of Property." Canadian Journal of Law and Jurisprudence 6 (1993): 217-248. Print.

Solchanyk, Roman. Ukraine and Russia: The Post-Soviet Transition. Maryland: Rowman and Littlefield, 2001. Print.

Steiner, Eva. French Law: A Comparative Approach. Oxford: Oxford UP, 2010. Print.

Subtelny, Orest. Ukraine: A History. University of Toronto Press, 2005. Print.

Sukhanov, Evgueny A. "The Right of Ownership in the Contemporary Civil Law of Russia." McGill Law Journal 44 (1999): 301-326. Print.

The Civil Code of Ukraine (2003) No. 435-IV-16.01.2003.

Tiede, Wolfgang, and Oscar Rennalls. "Recent Developments in the Ukrainian Judicial System and the Impact of International and European Law." East European Politics and Societies 26.1 (2012): 93-114. Print.

Twining, William. "Law, Justice and Rights: Some Implications of a Global Perspective." Environmental Law and Justice in Context. Eds. Jonas Ebbesson and Phoebe Okowa. Cambridge: Cambridge UP, 2009. 76-97. Print.

---. General Jurisprudence: Understanding Law from a Global Perspective. Cambridge UP, 2009. Print.

Varese, Federico. The Russian Mafia: Private Protection in a New Market Economy. Oxford: Oxford UP, 2001. Print.

“Vozdvizhenka District in Kiev, Ukraine 3." Photograph. Dreamstime.com. (C) Ksya (reproduction licensed), n.d. Web.

Wenar, Leif. Blood Oil: Tyrants, Violence and the Rules that Run the World. Oxford UP, 2016. Print.

Wilson, Andrew. The Ukrainians: Unexpected Nation. New Haven: Yale UP, 2009. Print.

Wolczuk, Kataryna. The Molding of Ukraine: The Constitutional Politics of State Formation. Central European UP, 2001. Print.

Ziff, Bruce. Principles of Property Law. Scarborough, Ontario: Carswell, 2000. Print.

Zimmerer, Gábor. "Raider Attacks in Ukraine." Transparency International Ukraine, 2012. Web. 11 Jan. 2016. <http://ti-ukraine.org/en/system/files/ research/raider_attacks_-_ti_ukraine_eng.pdf $>$. 
(c) 2016 East/West: Journal of Ukrainian Studies (ewjus.com) ISSN 2292-7956 Volume III, No. 1 (2016) 